\title{
THE FOOD OF LIFE AND THE SACRAMENT.
}

[CONCLUDED.]

\section{MITHRAS WORSHIP.}

THE Zarathustrian liturgy is called Yasna, or worship, and its 1 most important part is the Myazda offering, accompanied with water libations, the Zaothra, and a communion of the sacred cup of the haoma drink. The Myazda is a small piece of flesh taken from a milch cow placed upon a round wafer or cake, called draona. ${ }^{1}$ It is given to the faithful worshippers of Ahura Mazda with these words:

"Eat, $O$ ye men, of this Myazda, the meat-offering, ye who have deserved it by your righteousness and correctness.

"Mayest thou, O Ahura

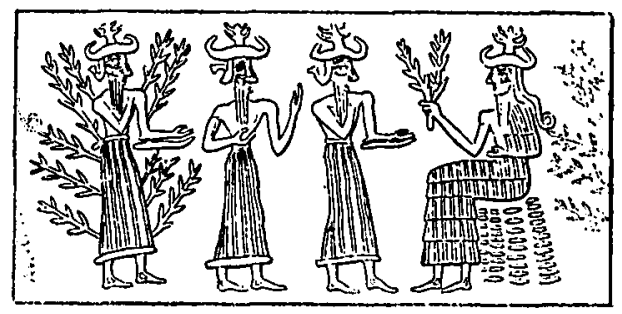

Assyrian Relibf From Nimrod." Mazda, reign at thy will and with a saving power rule over thine own creation,' etc. $^{3}$

All things connected with the Myazda ceremony are sacred, the words of the ritual, the wafers, the cup and the mortar in which the flour is prepared. Further, the twigs of pomegranate, date, or tamarind trees, which the priests hold in their hand; the cup and all other implements of this ceremony, are the weapons with

1 Afunagan, 3. Sacred Books of the East, Vol. XXXI., p. 368.

${ }^{2}$ Illustrating a spring festival celebrated with sacred sprigs. Layard, Mith., Plate XVI., 7 a.

${ }^{3}$ Yasna, VIII. S. B. of the E., Vol. XXXI., p. 229. 
which Angra Mainyu, the evil spirit, is overcome, in the same way as Christians may be said to conquer Satan through the holy Sacrament. Zarathustra threatens to smite Angra Mainyu and all his demons of evil, "till the fiend-smiting saviour comes up to life out of the lake Kûsava from the region of the dawn," and he adds: 1

"The sacred mortar, the sacred cup, the Haoma, the Words taught by Mazda, these are my best weapons. By this Word will I strike, by this Word will I repel, by this weapon the good creatures (will strike and repel thee), O Evil-doer, Angra Mainyu!"

The Saviour whose coming Zarathustra prophesies is the son of a virgin that became with child while bathing in the lake; and his name will be "the All-Conqueror, Righteousness Incarnate, the Benefactor, the Saviour." His arrival will usher in a millennium.

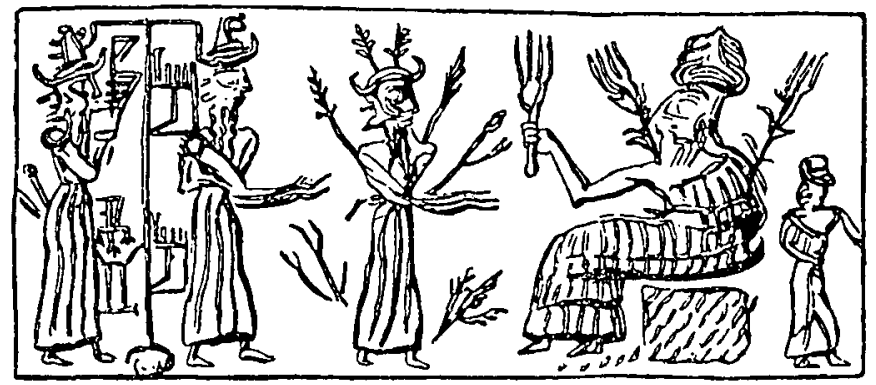

Side Surface of a Cone of Chalcedony. ${ }^{2}$

The world will be renewed; the dead will rise from their graves for judgment, and all the good will receive transfigured bodies that cast no shadows. This will be the Good Kingdom (Vohu Khshathra) or the kingdom wished for (Khshathra Vairya), which is personified as the spirit of God's Kingdom and plays a rôle not quite unlike to that of the Holy Ghost in Christianity.

The pious worshipper of Ahura Mazda prays for the coming of the kingdom:

"May Abura Mazda strengthen us through the Royal Power of the kingdom." Yasna, XLV., 9.

\footnotetext{
${ }^{1}$ Vendidad (Fargard XIX.). S. B. of the E., Vol. IV., p. 203-207.

2 Illustrating a spring festival celebrated with sacred sprigs. Layard, Mith., Plate XVI., 7a.
} 
The Yasna LIII. concludes with these words:

"Mazda, thine is that power and thine the kingdom, and by it thou bestowest the highest ${ }^{1}$ [bliss] on the righteous poor. ${ }^{2}$

Mithras, an old solar deity, probably older than Zarathustra, becomes with the ascendancy of Ahura-Mazda one of the archangels

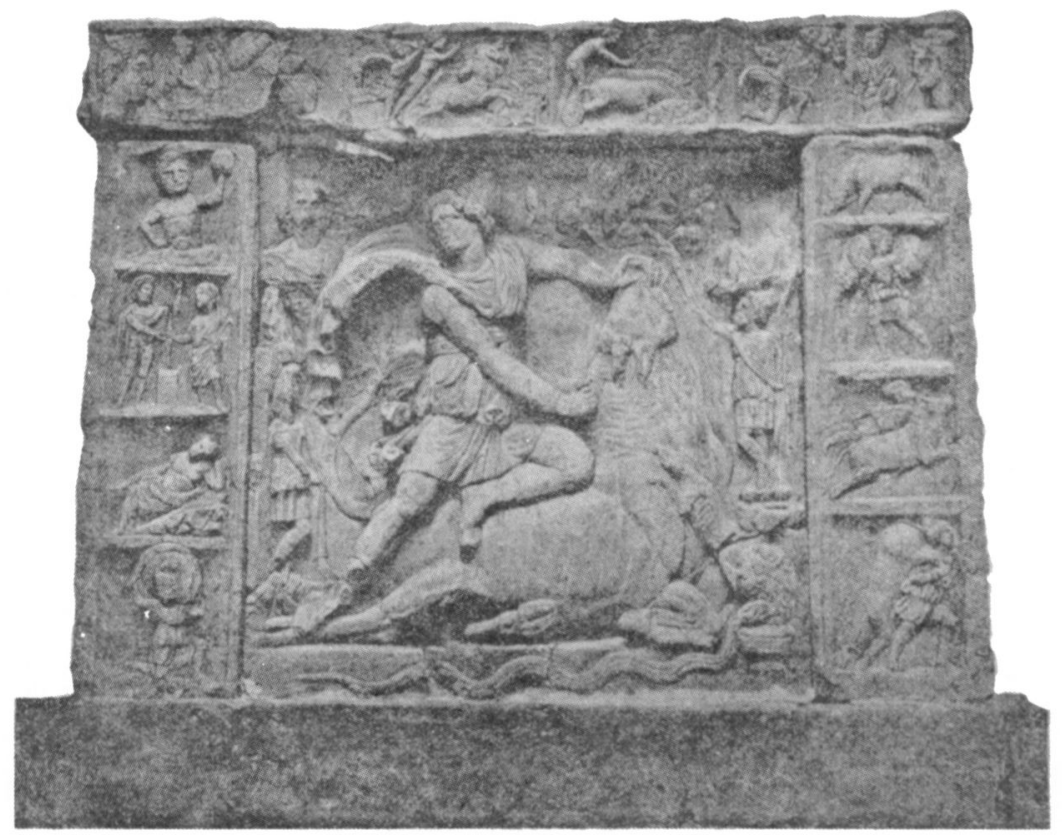

Bas-Relief of Neuenheim. ${ }^{3}$

and is more and more identified with the virgin-born Saviour whose coming Zarathustra has promised, assuming in the end a rank anal-

${ }^{1}$ The summum bonum.

${ }^{2}$ Zend-Avesta, Part III. S. B. of the E., Vol. XXXI., p. 194.

${ }^{3}$ This monument which has escaped the fate of mutilation by the hands of fanatics, was discovered in 1838 in a cave near Neuenheim, west of Heiligenberg, by workmen laying the foundation of a farm house. It is interesting because it shows very clearly twelve small bas-reliefs exhibiting scenes from the life of Mithras, beginning with his birth from the rocks on the top of the left border passing over to the right side where he catches the bull, carrying him to the cave so as not to show the footprints of his hoofs and ending on the top border, where his ascent to Ahura Mazda is represented. Some of the scenes have not yet been explained satisfactorily. Of interest is the second one, in which Ahura Mazda hands to Mithras the scepter of the government over the world. 
ogous to that which Christ holds in Christianity. In the Mihir Yast we read:

"Ahura Mazda spoke to Spitana Zarathustra, saying: 'Verily, when I made Mithra, the lord of wild pastures, ${ }^{1} \mathrm{O}$ Spitana, I created him as worthy of sacrifice, as worthy of prayer as myself, Abura Mazda.'"

In the days of Alexander the Great, Mithras worship was as

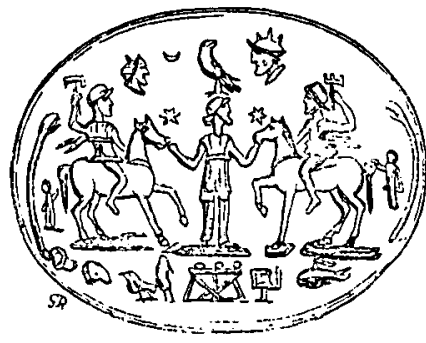

Mithras Between the Dioscuri.

(Ancient gem.) Underneath the altar with the Myazda wafers and the cup of the Mithraistic Eucharist. $^{3}$

to spread over the Roman Empire at the time of Trajan (97-I I7

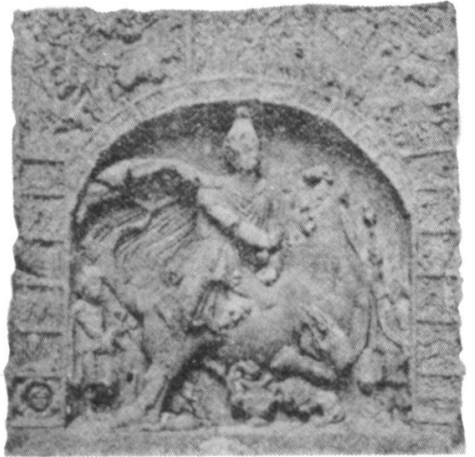

Mithras Monument of Ostburken. ${ }^{4}$ ship.

1 The word "wild" is probably an inept translation and might have been replaced by " wide, unbounded," or should be interpreted as " of natural growth."

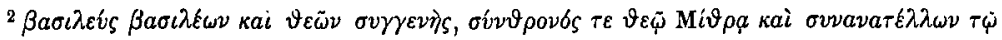
iniw. See Franz Cumont, Textes et monuments figurés relatifs aux mystéres de Mithra, II., pp. 37-38. Brussels, 1896.

${ }^{3}$ From Walsh, Ancient Coins, Medals, and Gems.

'Springer's Handbuch der Kunstgesch., I. p. 283. 
Mithras resembled Christ in several most significant features. $\mathrm{He}$ is not Ahura Mazda, the Lord Omniscient, himself, but a divine person equal in dignity to him; he is the high-priest of an atonement through blood, a saviour from eternal damnation, a leader in battle for the cause of righteousness, and a conqueror against whom the hosts of the fiend cannot prevail.

Mithras was born into the world from the rocks, perhaps symbolising the origin of fire from flint, and worshipped by shepherds, for the Persians are a pastoral people. He performed deeds of valor and slew, at the request of the Lord Omniscient, the glorious primordial bull from

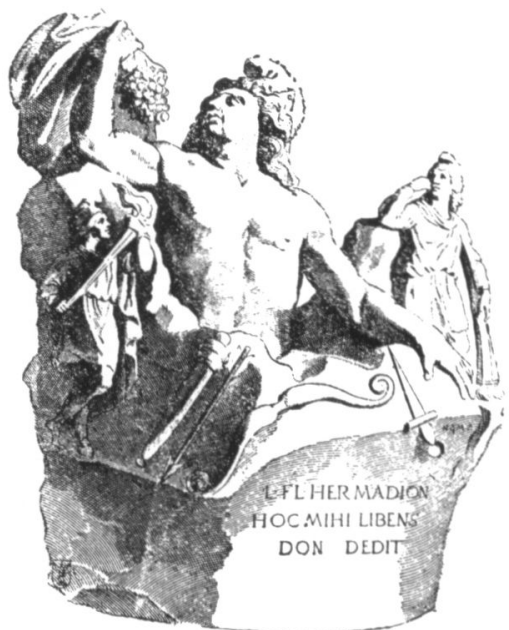

Mithras Born From the Rocks.

Holding in his hand the grape which replaces in the West the Haoma of the Persians. ${ }^{1}$ whose body he shaped the animate creation. He is called the

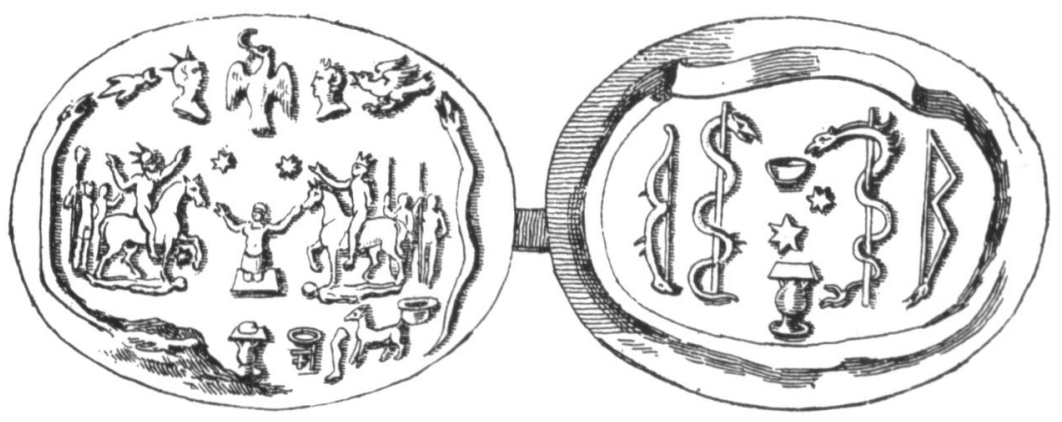

A Mithraistic Cameo.

Showing Mithras born from the rocks between the Dioscuri, surrounded by Mithraistic symbols, among them the cup and bread of the Eucharist.

mediator ( $\delta \mu \epsilon \sigma i \sigma \tau \eta s),{ }^{2}$ because before the end of this world he will rescue his creatures from sin through the sacrificial atonement of

\footnotetext{
${ }^{1}$ Reproduced from F. Cumont, p. 23I, after Lajard, Plate CIII.

${ }^{2}$ Plutarch, De Isid. et $0 ., 46$.
} 

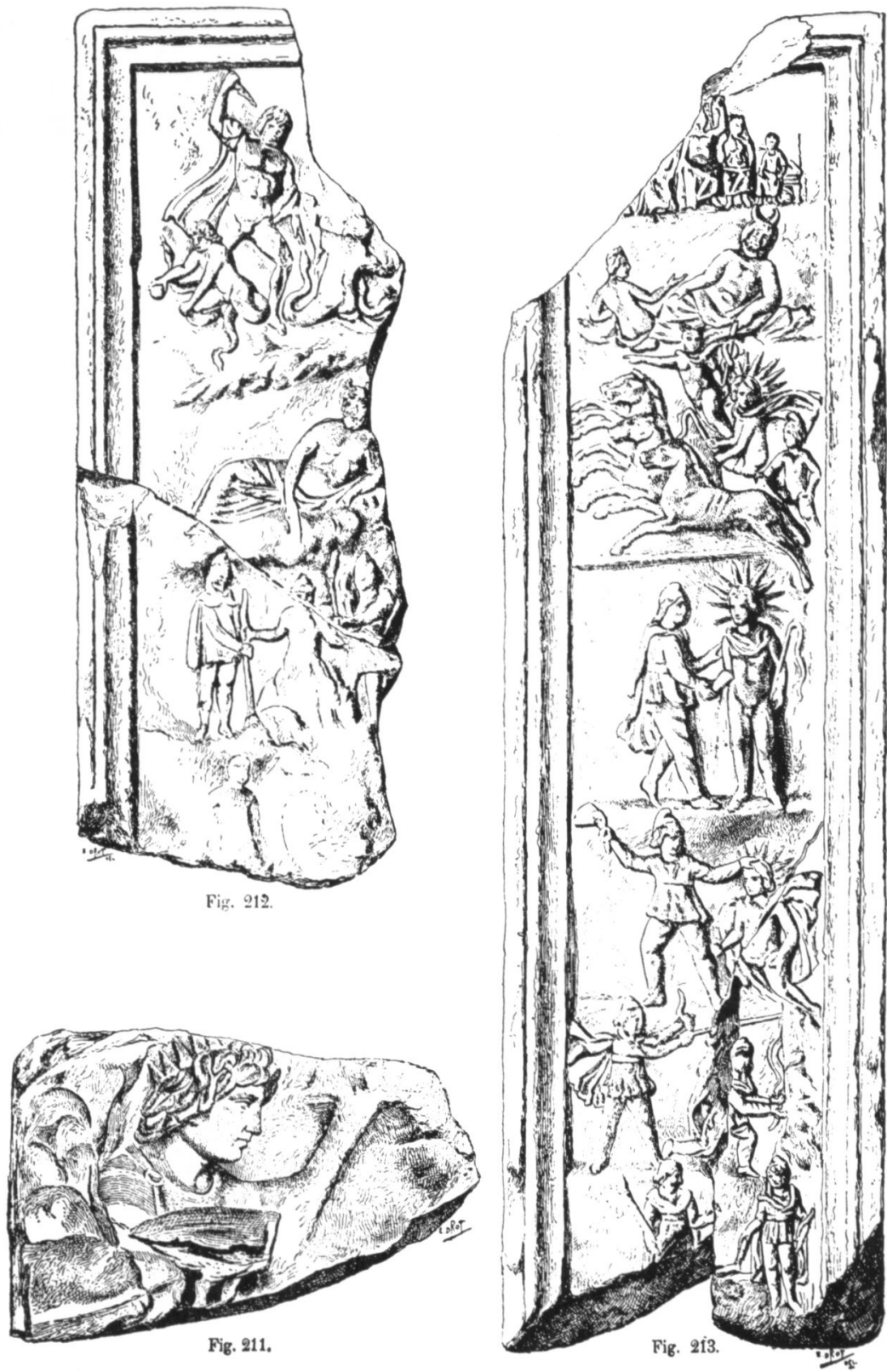

Fig. 211.

Fig. 213

Fragments of a Bas-Relief in White Italian Marble.

Found in the Zollfeld, now in the Historical Museum of the Rudolfinum at Klagenfurt, Austria. ${ }^{1}$

1 The central part of the monument is utterly destroyed, probably by Christian iconoclasts; the head of the sun-god from the left-hand corner alone being left. 
the blood of another bull of similar significance. Having fought the good fight for the salvation of mankind, Mithras ascends to heaven and prepares the millennium for his good and faithful followers.

The mysteries of Mithras were celebrated in a cave which Porphyry calls a symbol of the universe. ${ }^{1}$ In spite of the rigid monotheism of the Zendavesta, Mithras worship did not come

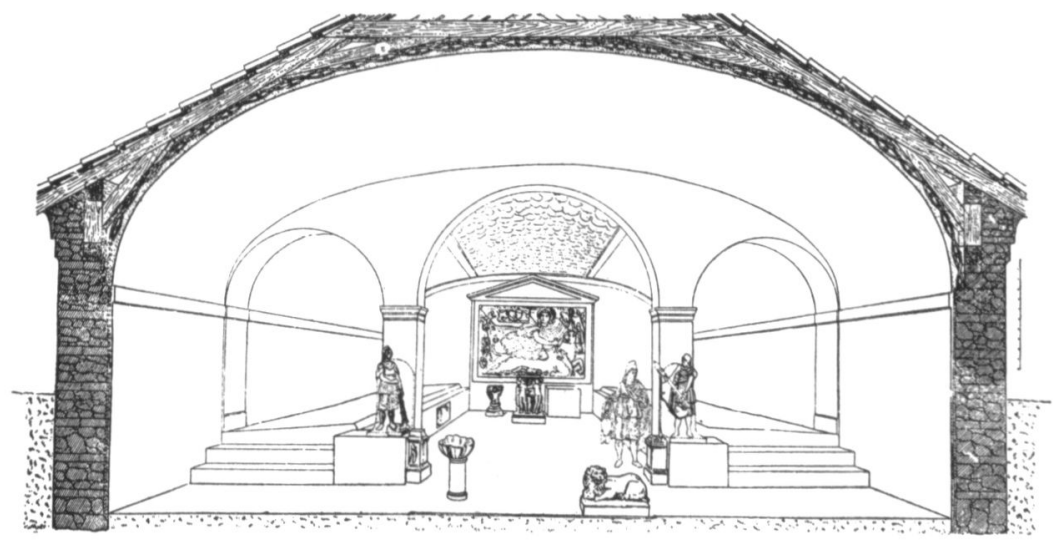

Mithreum, West of the Village of Petronell, Near Hintaus Ried, Austria. ${ }^{2}$ (Restored by Mr. Tragau.)

into conflict with the Pantheon of the Greek and Roman gods, for many of these were re-interpreted as equivalents of certain religious conceptions of Iran. Ahura Mazda was called Zeus Or-

The left border represents a Hellenised illustration of Ahura Mazda's struggle with demons, after the pattern of the giganto machia. The lower part of the same fragment exhibits the birth of Mithras and two shepherds who figure as torchbearers. The right border shows scenes from the life of Mithras, among them Mithras crowning the sun-god with a halo of rays and ascending in the solar charriot to heaven.

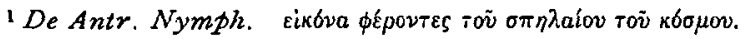

2 This Mitbræum, like all others of the same style is underground. Before the great bas-relief of Mithras slaying the bull are two altars, the one large and square in form, the other smaller and richly ornamented. The small statue on the left is Mithras being born from the rocks. At the entrance we see on the right the lion of Mithras and on the left a fount for holy water. The two torch-bearers have their stand at the pillars which separate the aisles. The Mithræum is approached by a staircase and through a square hall (or pronaos) which is considerably larger than the sanctum itself. 
$\operatorname{madz}$; a personification of the Haoma drink was identified with Dionysus. The sun became Helios, the moon Artemis, the seven planets were represented after Greek fashion, etc.

The sacred cup and the bread wafers are frequently represented upon Mithraistic medals, and the church-fathers declare

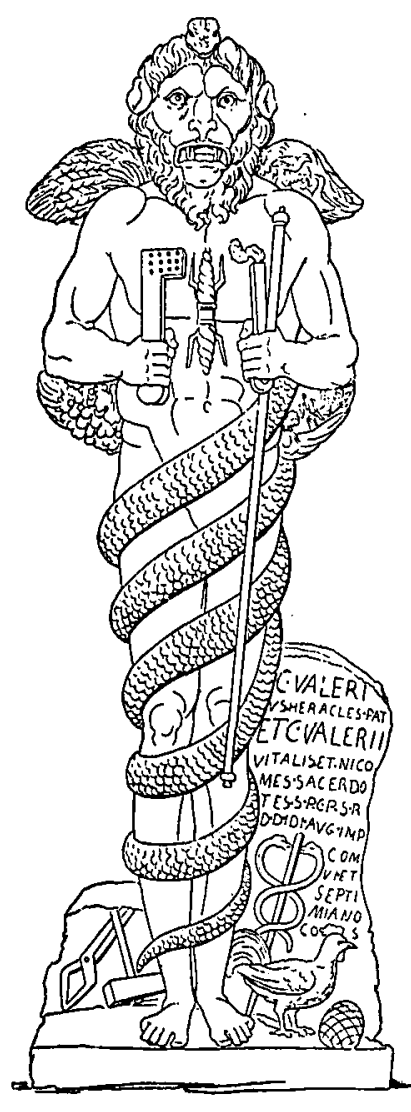

ÆON OR ZRVAN AKarana. Unlimited Time. ${ }^{1}$ that devils had imitated in the Mithraistic rites the sacraments of the Lord. With all due deference to the opinion of these saintly men, we must remember that Mazdaism with its sacramental rites including the offering of the Haoma drink and the Myazda cakes, is older by several centuries than Christianity.

Monuments discovered all over the Roman Empire constitute one of the most important sources of Mithras worship. Few of them are in good preservation, for the religious fanaticism of the third and fourth centuries destroyed some and mutilated others. Some figures are quite puzzling at first, but patient inquiry has succeeded in unravelling all the salient features of this remarkable religion.

There are innumerable Mithraeums with altar-pieces representing the sacrifice of the sacred bull by the hand of Mithras, on either side a daduchos or torch-bearer, one holding his torch upward, the other downward. There are innumerable gems with Mithraistic symbols on them, and scenes from the life of Mithras, among them the official transfer of the

1 The statue here reproduced was found in the Mithraeum of Ostia, where C. Valerius Heracles and his sons dedicated it in the year 190 A.D.; it was figured for the first time by Lajard in his Recherches sur Mithra, Plate LXX. Similar statues are found in various Mithras caves. 
world's government to him by the Creator Ahura Mazda, his divine father.

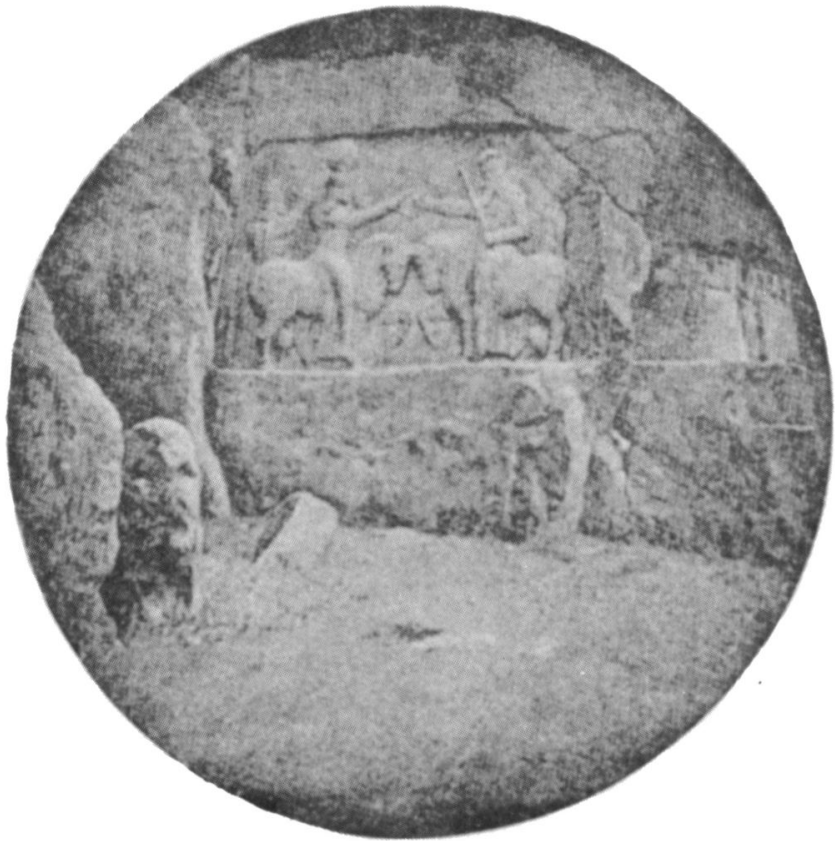

Sassanian Bas-Relief. Ormazd Presents the Crown to Ardashir. (From Curzon, Persia, II. p. I25.)

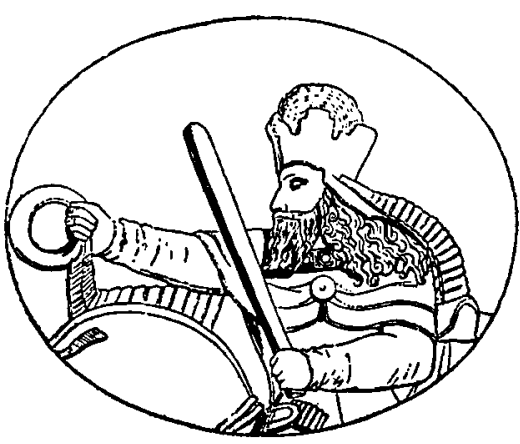

Ormazd with the Circle of Sovereignty AND THE SCEPTRE OF PoWBr.

(From the Sassanian bas-relief.)

On ancient Persian monuments Ahura Mazda is represented mostly as governing the world and giving umbrage to kings or as 
transferring the ring of sovereignty to his anointed vicegerents on earth. They differ from Christian representations of analogous scenes mainly in exhibiting a more martial character.

Eon, the lion-faced, with key, torch, and measuring staff is a divinity of considerable importance in the religion of Mithras. $\mathrm{He}$ is the Zrvan Akarana (Time unlimited) of the Zend Avesta, not so much a personality as a personified abstraction, representing the

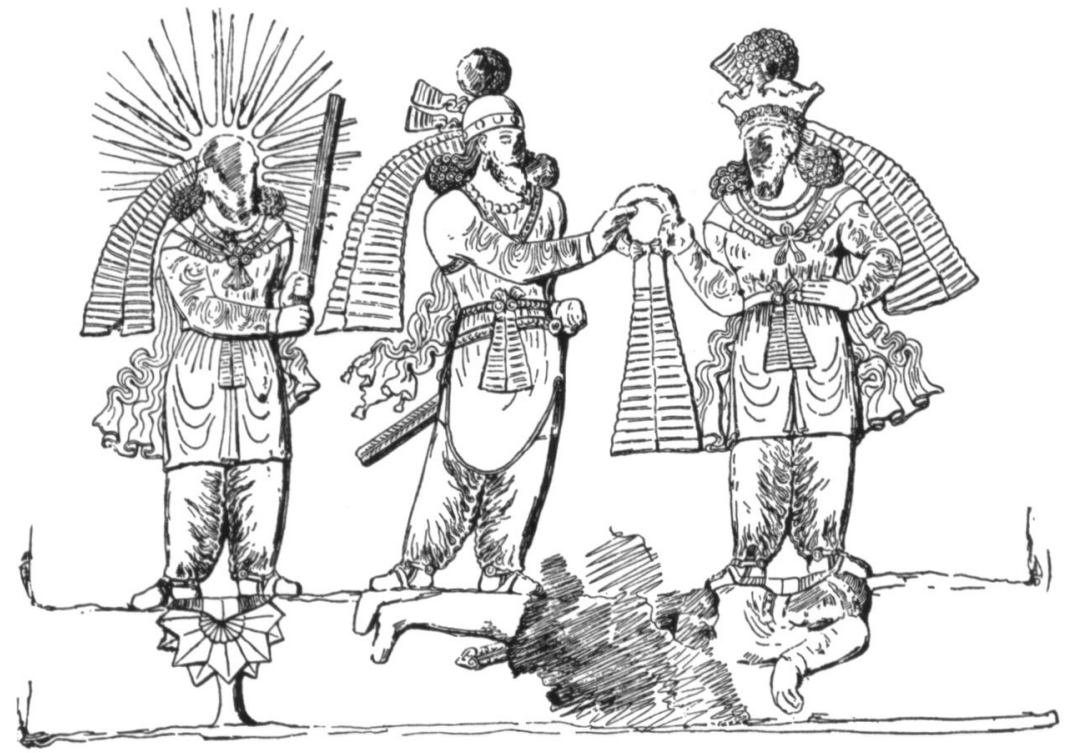

The Takht-i Bostan Sculpture. ${ }^{1}$

primordial state of existence from which Ahura Mazda is born. Statues of Æon are found in many Mithræums, displaying re-

${ }^{1}$ Not far from Behistan near the city of Kermanshâh in the valley of TakhtiBostan there are sculptures on a rock supposed to contain a representation of Zoroaster. The sixth group, which is the last in the row, exhibits three standing figures with a fourth one being trampled under foot by the two crowned men on the right hand side. It may represent Ormazd or Ahura Mazda, the Lord Omniscient banding the ring of sovereignity to Mithras after the final conquest of Ahriman. But it may as well be an Iranian king rewarding his victorious son by making him sharer in the rule of empire. The downtrodden foe would be the enemy of Mazdaism, a figure representing the conquered Arsacidx. The man behind the King standing upon a tree, holding a staff in his hands and surrounded with a balo of rays is commonly and perhaps without exception assumed to be Zoroastra the prophet. 
markable crudity of invention. The serpent's coils that surround his body represent the revolutions of time, his wings the four seasons. His relation to the deities of the Greek pantheon, Hephæstus, Esculapius, Hermes, and Dionysius, is indicated by the presence of their emblems.

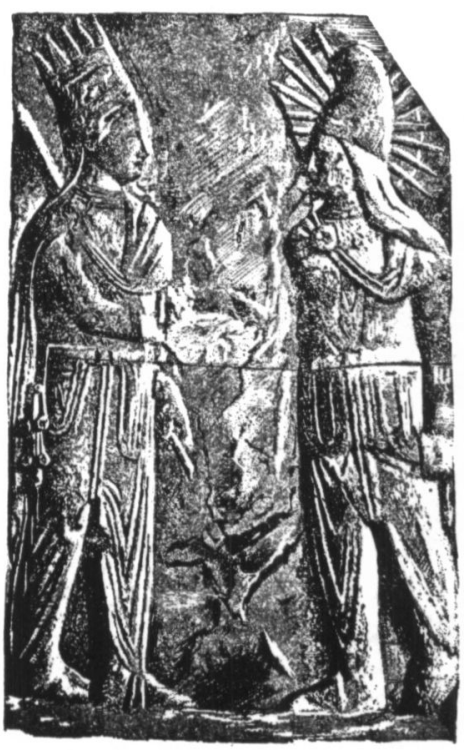

Mithras and King Antiochus OF COMMAGENE.

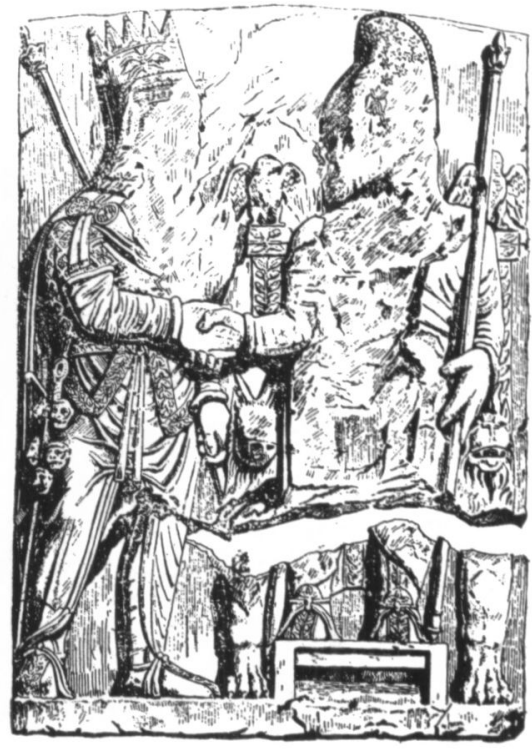

Ahura Mazda and Artagenes.

Bas-reliefs of a temple built by Antiochus I. (69-34 B. C.) on the Nemrood Dagh, Taurus Mountains. ${ }^{1}$

The most important passages concerning Mithras worship are found in the writings of Justinus Martyr and Tertullian. Justinus says :

"The Apostles, in the memoirs composed by them, which are called Gospels, have thus delivered unto us what was enjoined upon them; that Jesus took bread, and when he had given thanks, said, 'This do ye in remembrance of me, this is my body:' and that, after the same manner, having taken the cup and given thanks, he said, 'This is my blood'; and gave it to them alone. Which the wicked devils have imitated in the mysteries of Mithras, commanding the same thing to be done. For, that bread and a cup of water are placed with certain incantations in the

${ }^{1}$ From Franz Cumont (l. l., p. 188) after Hermann und Puchstein, Reisen in Klein Asien, Berlin, 189o, Plate XXVIII., 2, cf. pp. 321 ff., and Plate XXXI., I. 
mystic rites of one who is being initiated, you either know or can learn." Ante. Nicene Christian Library-Justin Martyr, Vol. II., p. 65.

Tertullian is a little more explicit, but agrees in sentiment as well as in his opinion with Justinus Martyr. In a passage where he declares that Christian heresies like Pagan religions are in-

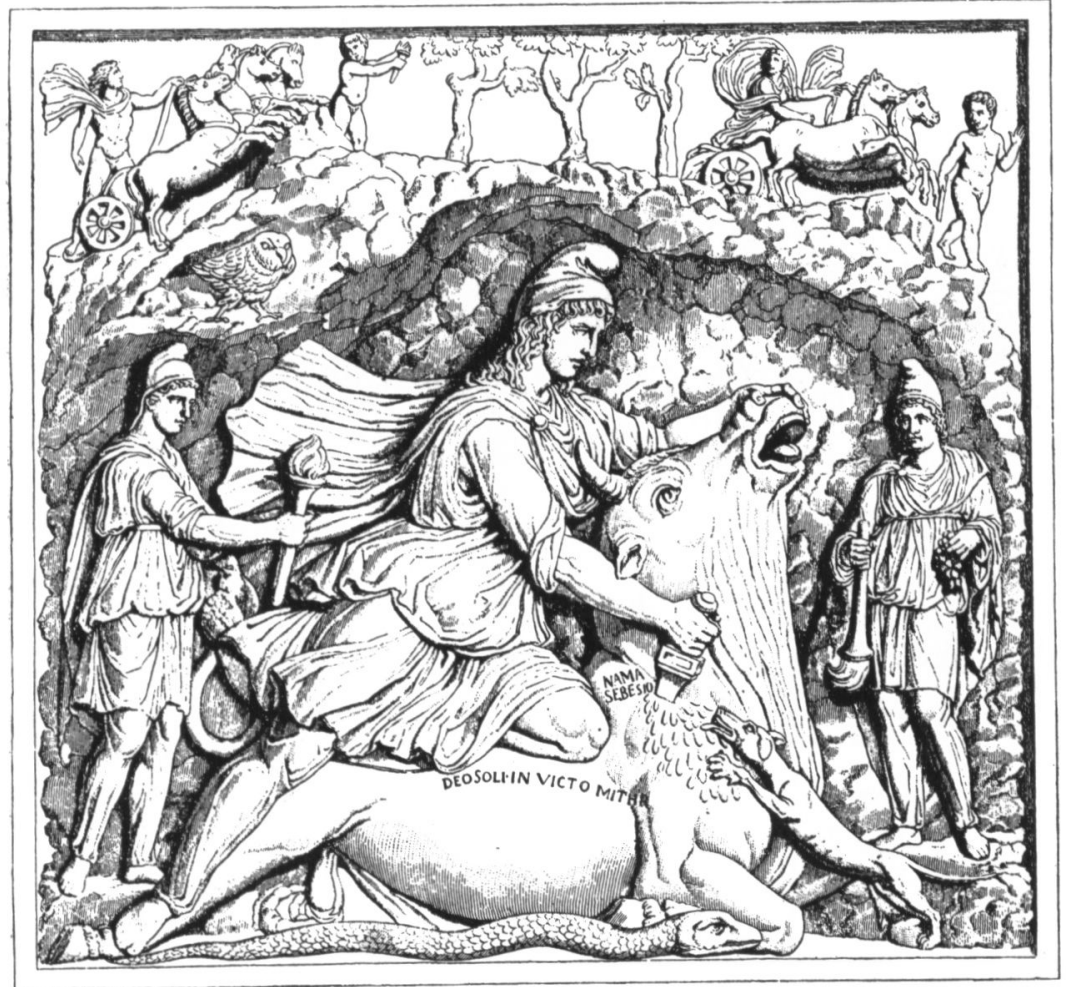

Mithras the Saviour. (Borghesi Monument, now at the Louvre in Paris.) ${ }^{1}$

ventions of the Devil, he mentions Mithras worship on account of its obvious similarity to the Christian ritual, adding that even the ideal of chastity is recognised by the Pagans, since they have insti-

1 The monument bears the inscription "Deo Soli Invicto Mithrae." Mithras sacrifices in a cave a bull for the forgiveness of sins. A dog licks the dripping blood, called "nama sebesion" (the sacred fluid). A serpent crawls on the ground. A scorpion pinches off the bull's testicles. A youth at the left turns a torch upwards, at the right, downwards. A raven, which here looks like an owl, witnesses thescene. Over the cave, the sungod, Helios, and the goddess of the moon, Selene, drive past in their chariots. 
tutions like Christian nunneries, and their high-priest, being a widower, is not allowed to marry again. He must be one wife's husband for time and eternity, an injunction which St. Paul would also make for a Christian bishop (I Tim. iii. 2).
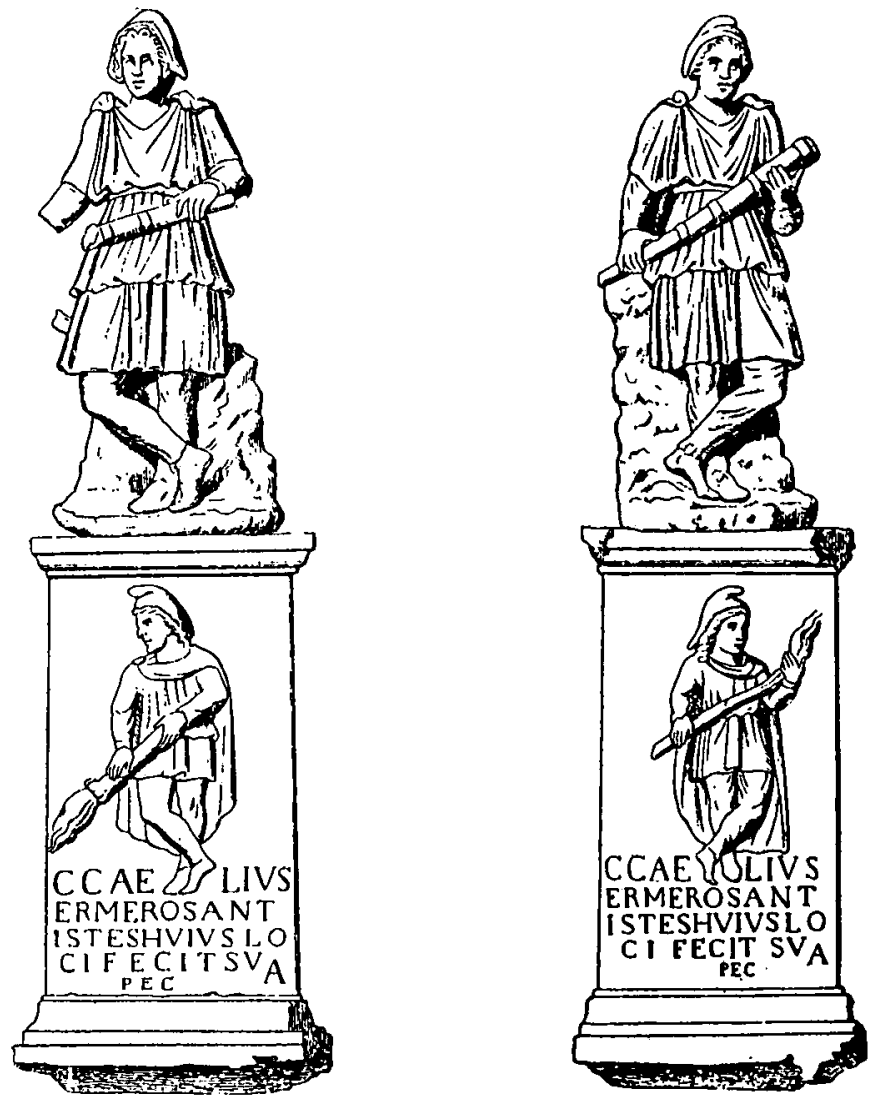

Statues of Torchbearers in a Mithraum of Ostia.

Now in the Lateran.

Tertullian says in his prescription against heretics, Chap. XL:

" The very Scriptures were even arranged by the will of God in such a manner as to furnish materials for heretics, inasmuch as I read that 'there must be heresies,' which there cannot be without the Scriptures.

"The question will arise, By whom is to be interpreted the sense of the passages which make for heresies? By the devil, of course, to whom pertain those wiles which pervert the truth, and who, by the mystic rites of his idols, vies even with the essential portions of the sacraments of God. 
" He, too, baptises some, -that is, his own believers and faithful followers; he promises the putting away of sins by a laver [of his own]; and if my memory still serves me, Mithra there [in the kingdom of Satan] sets his marks on the foreheads of his soldiers; celebrates also the oblation of bread, and introduces an image of a resurrection, and before a sword wreathes a crown.

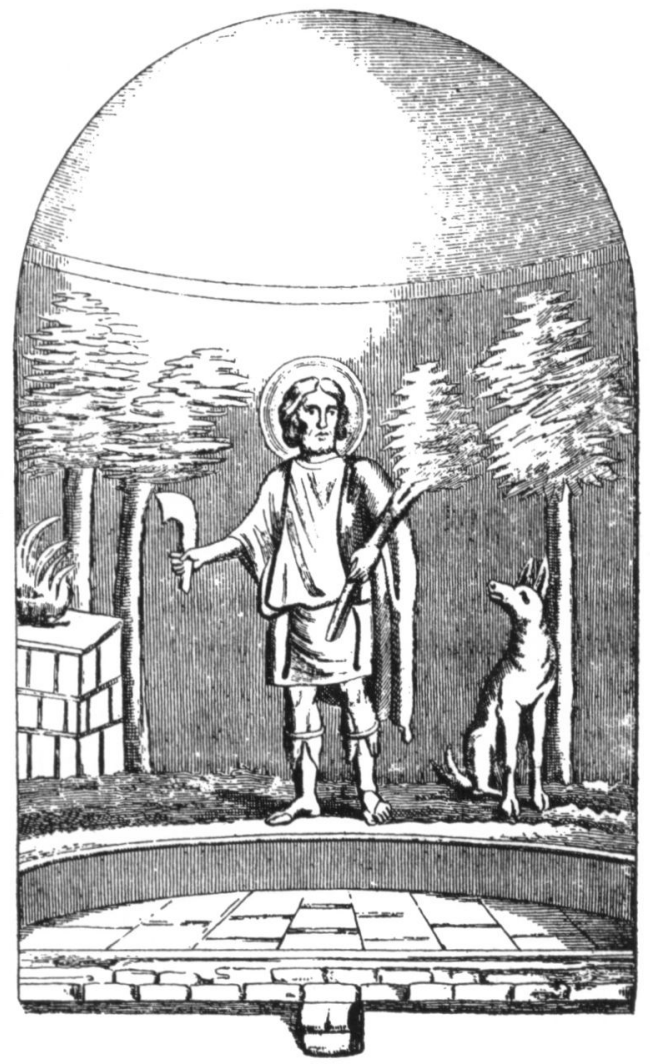

Silvanus.

Picture in the niche of a sanctury connected with the Mithræum in Ostia near the baths built by Antoninus Pius. Silvanus is ready to act as a priest of Mithras, having in one hand a fir branch, in the other a hatchet such as are frequently found in the ruins of Mithræums.

"What also must we say to [Satan's] limiting his chief priest to a single marriage? He, too, has his virgins; he, too, has his proficients in continence. Suppose now we revolve in our minds the superstitions of Numa Pompilius, and consider his priestly offices and badges, and privileges, his sacrificial services, too, and the instruments and vessels of the sacrifices themselves, and the curious rites 
of his expiations and vows: is it not clear to us that the devil imitated the wellknown moroseness of the Jewish law?

"Since, therefore, he has shown such emulation in his great aim of expressing, in the concerns of his idolatry, those very things of which consists the administration of Christ's sacraments, it follows, of course, that the same being, possessing still the same genius, both set his heart upon, and succeeded in, adapting to his profane and rival creed the very documents of divine things and of the Christian saints, - his interpretation from their interpretations, his words from their words, his parables from their parables. For this reason, then, no one ought to doubt, either that 'spiritual wickednesses,' from which also heresies come, have been introduced by the devil, or that there is any real difference between heresies and idolatry, seeing that they appertain both to the same author and the same work that idolatry does."

The crown was a Christian symbol, and the sword of martyrdom was welcome to those who were eager to receive the crown of

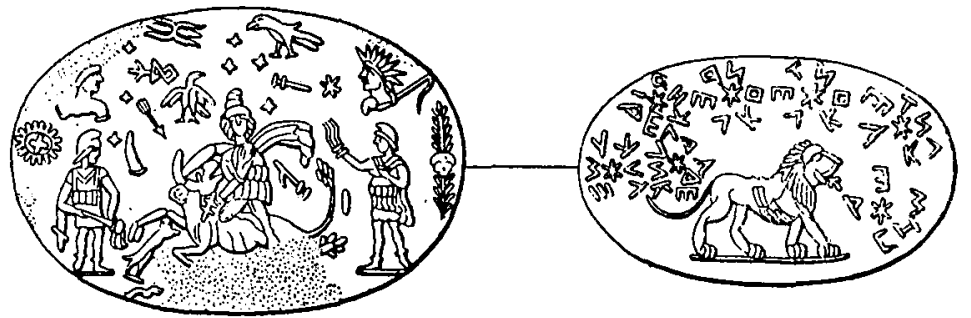

Plague of Heliotrope Agate Representing Mithraistic Symbols.

(Engraved in intaglio and used as a seal.)

life of which the Apostle speaks, - a crown of unfading flowers. The soldiers of Mithras, which is the name of one of the seven degrees, were, when initiated into the fraternity, made conscious that they must be fighters, and so a sword was placed on their heads, for they should be ready to die for the cause of the god of

'The front exhibits the bull-slaying Mithras, the dadouchoi or torch-bearers, the dog, the scorpion, the raven, the snake (mostly destroyed) the sun-god, the moon-goddess, all of which occur on every Mithras monument, and in addition an eagle with spread wings, the seven planets (not counting the sun before the sun-god which was a different shape) the thunderbolt of Zeus, the harp of Saturn (below the mantle of Mithras and partly injured), a halo of rays with a cross, a tree with a mask (perhaps a skull), the staff of Hermes, an arrow (of Mars?). The reverse represents the lion of Mithras with a bee in his mouth and the seven planets with their names in an unknown tongue. The frequent occurrence of EL and AL, i. e., God, the former form appearing five times, the latter twice, indicates that we have to do with a semitic dialect. 
light, but at the same time they should scorn the transient flowers of worldly crowns, because a soldier of Mithras glories only in the immortal crown that will never perish, which is Mithras. Tertullian says in the last chapter of his essay on the crown:

"What have you in common with the flower which is to die? You have a flower in the Branch of Jesse, upon which the grace of the Divine Spirit in all its fulness rested, - a flower undefiled, unfading, everlasting, by choosing which the good soldier, too, has got promotion in the heavenly ranks. Blush, ye fellowsoldiers of Christ, henceforth not to be condemned even by him, but by some soldier of Mithras, who, at his initiation in the gloomy cavern, in the camp, it may well be said, of darkness, when at the sword's point a crown is presented to him, as though in mimicry of martyrdom, and thereupon put upon his head, is admonished to resist and cast it off, and transfer it to his shoulder, saying that Mithras is his crown. And thenceforth he is never crowned; and he has that for a mark to show who he is, if anywhere he be subjected to trial in respect of his religion; and he is at once believed to be a soldier of Mithras if he throws the crown away, - if he say that in his god he has his crown. Let us take note of the devices of the devil, who is wont to ape some of God's things with no other design than, by the faithfulness of his servants, to put us to shame, and to condemn us." 1

Professor Franz Cumont, perhaps the best authority on the subject, sums up his opinion as follows :

"When the reader reconsiders what we have stated about the religion of Mithras, he will be surprised at its similarity to Christianity. Like the Christians, so the adherents of the Persian god lived in close relationship with one another, using the terms 'fathers ' and 'brothers.' Like the Christians, they had baptism, a kind of communion; they taught an imperative morality, preached continence, chastity, self-abnegation, and self-control. They speak of a deluge, believe in the immortality of the soul as well as the resurrection of the dead, in a beaven of the blessed ones and a hell inhabited by the powers of evil. We have seen that the theology of the mysteries conceived Mithras as equivalent to the Alexandrian Logos. We may fairly assume that these features are not the sole similarities between him and Christ, and that the illustration of the god sacrificing against his

${ }^{1}$ I refrain from heaping quotations, and refer the reader to the second volume of Franz Cumot's work on the texts and monuments of Mithras (quoted above) which contains a diligent collection of almost six hundred passages relating to Mithras worship. The enormous number of Mithraistic monuments and allusions to Mithras in the writings of antiquity prove the great extension of Mithras worship. For our present purpose no passages are of more importance than those quoted above. 
inclination the primordial bull ${ }^{1}$ for the purpose of creating the human kind and then redeeming it from death, has been compared with the Saviour who sacrificed himself for the salvation of the world. We could even trace the worship of the shepherds, a communion scene, and an ascension of Mithras to beaven in those legends. Augustine tells us that he had met a Mithras priest (Pileati sacerdotem ${ }^{2}$ ) who used to say, 'The Hooded One himself is Christian' (et ipse Pileatus christianus est). Since the second century the pagan philosophers began to contrast the Persian mysteries with Christianity, apparently to exhibit their superiority (Celsius in Origen's Contra Celsizm), while on the other hand the church-fathers insist on the explanation of these analogies between both religions as due to an imitation of devils." 3

Considering the similarity of the Christian communion to the Myazda offering of the Mithras worshippers, the suggestion offers itself that the very name of the Lord's Supper among the Romans, which is Missa (or in English "Mass"), the etymology of which is as yet an unsolved problem, might have been derived from the word Myazda. ${ }^{4}$

If Mithras worship was so similar to Christianity, the question seems in order as to why it disappeared and left no traces. M. Renan goes so far as to say that if Christianity had ever been checked in its expansion, the world would now be Mithraistic. We beg to differ from this opinion and would suggest the following explanation as the most plausible reason for the failure of Mithraism.

Mithras worship, as practised in the Roman camps, was not so much a religion free to all and preached on the housetops, as a ceremonial of a secret society. Accordingly a Mithræum was not so much like a church as it was like a masonic lodge, and the worshippers of Mithras were not a congregation open to the rich and the poor alike, but an aristocratic fraternity of seven degrees, the

${ }^{1}$ Christ is frequently compared to a white bull in the Book of Enoch and other apocrypha.

${ }^{2}$ Pileatus, i. e., "the Hooded One," is a cognomen of Mithras.

${ }^{3}$ Roscher's Lex. d. G, u. R. Mychologie, pp. 3066-3067.

"We deem it not at all improbable that the word "Myazda" was imported into Hebrew to denote the unleavened bread, eaten at the festival of the unleavened bread, which is called in the Bible $7 \$$ (matztza). This term does not look like an original Hebrew word, and is certainly not derived from the Hebrew root of the same sound מצה, which means "to suck." 
members of which had to be initiated by passing through an elaborate system of ordeals, of which traces are perhaps still preserved in the masonic order. While Mithraism was apparently very exclusive, Christianity adopted many Mithraistic conceptions and in. stitutions. Christian authors set forth with a logic that is peculiarly their own the arguments as to why it was proper to celebrate the Nativity of Christ on the very same day on which the Pagans celebrated the nativity of Mithras. ${ }^{1}$

For a while Mithraism flourished, especially after the reign of Commodus who was initiated into its mysteries. It was fashion-

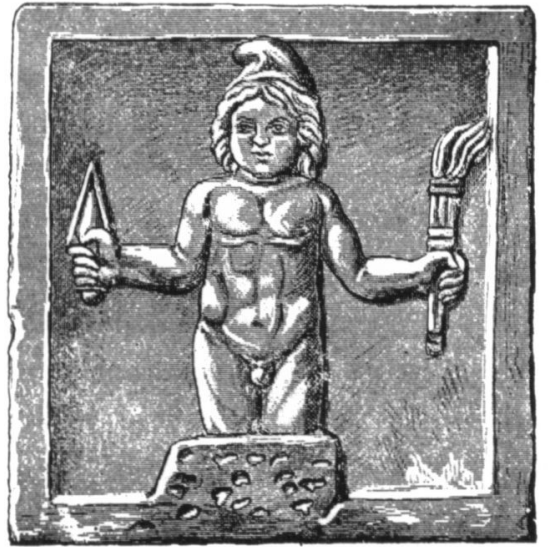

Mithras Born from the Rocks. ${ }^{2}$

With the dagger of sacrifice symbolising the vicarious atonement through blood and the torch of enlightenment.

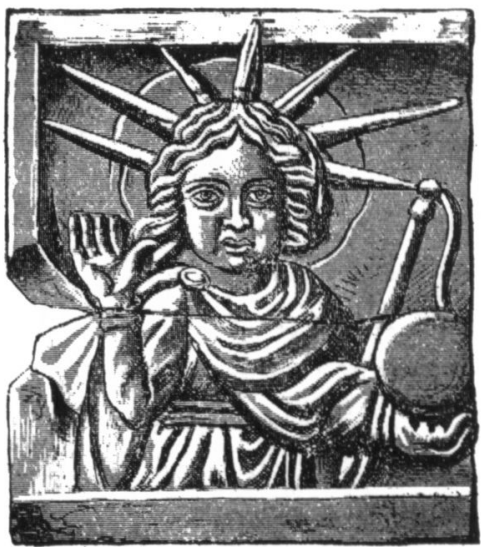

Sol The Sun-God, ${ }^{2}$

Installed by Mithras as the governor of the world, as indicated by the halo of rays and the globe of power.

able, and presumably expensive. But when Constantine threw the weight of imperial favor into the balance of Christianity the fate of Mithraism was sealed forever.

Whether or not the Zarathustrian Myazda offering is historically connected with the Assyrian myth of the food of life, we have no means of ascertaining, but we need not hesitate to say that prob-

${ }^{1}$ For details see The Open Conert, Vol. XIII., No. 12, pp. 725-730, in an article on "The Nativity."

${ }^{2}$ Reproduced from Cumont $(l, l$. II., p. I88, figures 10 and II). 
ably it is. At any rate, it is based upon the same idea, and there are analogous institutions among savages and semi-civilised people all over the world.

CHRISTIAN RITES: THE BREAKING OF BREAD, THE AGAPE AND THE LORD'S SUPPER.

Considering the all but universal usage of symbolising the preservation of life by a sacramental eating of some primitive food, we must expect to find traces of the idea in the ritual of the Hebrews; and indeed communion meals are a fundamental principle in the ancient Jewish institutions. The father of the family broke the bread and gave thanks, saying: "Blessed is he who created the fruit of the earth"; and raising the cup, he added: "Blessed is he who created the fruit of the vine." 1 This custom was most punctiliously adhered to by all pious Jews, and we know that Jesus observed this tradition of his people whenever an opportunity offered itself. This appears especially from the Synoptic Gospels where they relate the miracle of the five loaves and the fishes. Mark (the oldest account of the three) says ${ }^{2}$ :

"And when he had taken the tive loaves and the two fishes, he looked up to heaven, and blessed, and brake the loaves, and gave them to his disciples to set before them; and the two fishes divided he among them all."

The same miracle is reported twice by Matthew and Mark, only with this variation that the second time seven loaves are mentioned instead of five, and seven baskets full are saved instead of twelve. ${ }^{3}$

The congregation of Jerusalem continued the practice of breaking bread, which (as we learn from Acts ii. 42) was not done in the temple, or in a synagogue, or in any official place of worship, but in the houses of the Nazarene brethren.

That the early Christians celebrated love feasts or feasts of charity is apparent from passages in the second epistle of St. Peter

1 "Benedictus qui creavit fructum terrae: benedictus qui producit panem e terra :" and "benedictus qui creavit fructum vitis." I. Tr. Beraehoth VI. I.

${ }^{2}$ See also Matth. xiv. I9, and Luke ix. I6.

${ }^{3}$ See Matth. xv. $3^{6}$, and Mark viii. 6. 
and the epistle of St. Jude $;^{1}$ the custom is also alluded to in the Revelation of St. John; and judging from the description of early Christian life at Jerusalem in the Acts, we cannot doubt that the communal meals of the Christians were simply a continuation of the same pre-Christian practice. There is no evidence whatever for the assumption that in the early days of Christianity the eucharist and the agape were different institutions. On the contrary they are quite undistinguishable, and if there is anything that characterises them in distinction from ordinary meals it is the practice of breaking the bread and giving thanks. This practice, however, is (as we have seen) not exclusively Christian, but was practised in Judæa, mainly by earnest sectarians, such as the Nazarenes and the disciples of St. John the Baptist, congregations, which, as we know, had been exposed to Persian influences and entertained many Gnostic notions. It is peculiar that the days for these communal meals of breaking the bread and giving thanks were not the Sabbath, but the Sunday, the sacred day of Mithras.

The disciples at Troas are specially reported to have met on Sundays. That Paul should have introduced this custom in celebration of the rising of Christ is neither reported in the Acts nor is there any justification to imply it. The day of resurrection was by no means fixed among the early Christians, for sometimes it is reported that Christ would rise on the third day, and then again after three days, which would bring the event down to Monday in the afternoon. The statement in the Acts is quite explicit that the congregation of disciples whom St. Paul visits in Troas celebrated Sundays with a communal bread-breaking before their conversion, and the fact is represented as the prevailing custom in these words:

"And we sailed away from Philippi after the days of unleavened bread, and came unto them to Troas in five days; where we abode seven days.

"And upon the first day of the week, when the disciples came together to break bread, Paul preached unto them, ready to depart on the morrow; and continued his speech until midnight."

We cannot very well assume that "the disciples of Troas" were Christians before St. Paul's arrival. Disciples is a name of

${ }^{1}$ Ep. St. Jude 12. 
the Zabeans, the sect to which John the Baptist belonged as we know, e. g., from the report in Chapter xix. of the Acts. The respect paid to the sun by the Essenes, with other indications of Mithraistic influences, makes it probable that it was an un-Jewish influence which caused the Sunday to be so commonly regarded as the proper day for the celebration of love feasts.

The Christian love feast, or as the Greek called it, agape, was a common dinner, and we learn from the first Epistle of St. Paul to the Corinthians that its celebration was very different from both

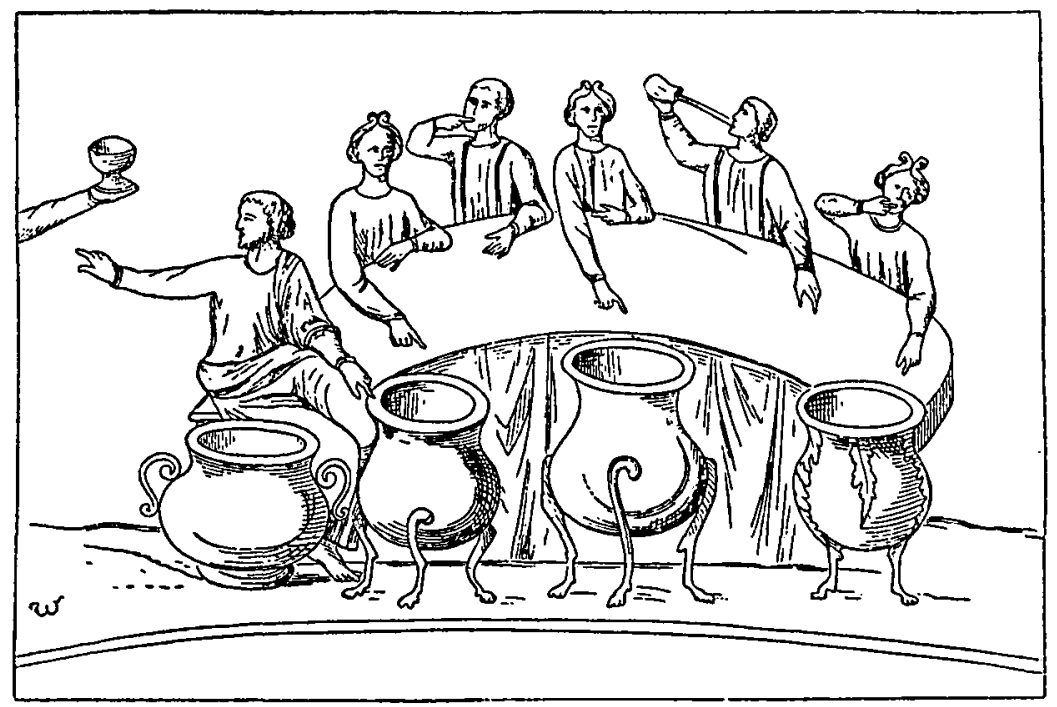

The Marriage Feast of Cana Represented as a Eucharistia.

Fresco in the cemetery of St. Pietro e Marcellino.

the Roman Mass and the Lord's Supper of the Protestants. It was different, too, from the Nazarene bread-breaking of the early Christians at Jerusalem. It was no longer taken in the homes of the brethren (as practised by the Nazarenes of Jerusalem), but in the church after the fashion of modern picnics, and was even less brotherly; for every one brought his own meal along and ate for himself. It lacked dignity and was sometimes disturbed by disorderly conduct. St. Paul takes the Corinthians severely to task and requests them to remember in their "eucharistia" the sacrificial death and the resurrection of the Lord. 
As the passage is of great importance, we quote it in full:

"When ye come together therefore into one place, this is not [the way] to eat the Lord's supper.

"For in eating every one taketh before other his own supper: and one is hungry, and another is drunken.

"What? have ye not houses to eat and to drink in ? or despise ye the church of God, and shame them that are needy? What shall I say to you ? shall I praise you in this? I praise you not.

"For I have received of the Lord that which also I delivered unto you, That the Lord Jesus the same night in which he was betrayed took bread:

"And when he bad given thanks, he brake it, and said:

"Take, eat : this is my body, which is broken for you : this do in remembrance of me.

"After the same manner also he took the cup, when he had supped, saying.

"This cup is the new testament in my blood: this do ye, as oft as ye drink it, in remembrance of me.

"For as often as ye eat this bread, and drink this cup, ye do show the Lord's death till he come.

"Wherefore whosoever shall eat this bread, and drink this cup of the Lord, unworthily, shall be guilty of the body and blood of the Lord.

"But let a man examine himself, and so let him eat of that bread, and drink of that cup.

"For he that eateth and drinketh unworthily, eateth and drinketh damnation to himself, not discerning the Lord's body.

"For this cause many are weak and sickly among you, and many sleep.

"For if we would judge ourselves, we should not be judged.

"But when we are judged, we are chastened of the Lord, that we should not be condemned with the world.

"Wherefore, my brethren, when ye come together to eat, tarry one for another.

"And if any man hunger, let him eat at home; that ye come not together unto condemnation. And the rest will I set in order when I come." (I Cor. xi. 20-34.)

The moral seriousness of St. Paul's reformatory activity wrought a great change in the celebration of the eucharist.

The next important report as to the way in which the sacrament was celebrated among the early Christians is found in the first apology of Justin Martyr, which reads as follows :

"After the believer is baptised, and so incorporated or made one with us, we lead him to the congregation of the brethren, as we call them, and then with great fervency pour out our souls in common prayers both for ourselves, for the person 
baptised, and for all others all the world over; that having embraced the trutb, our conversation might be as becometh the Gospel, and that we may be found doers of the word, and so at length be saved with an everlasting salvation. Prayers being over, we salute each other with a kiss. After this, bread [and a cup of wine'] and water are brought to the president or bishop, which he takes, and offers up praise and glory to the Father of all things, through the name of His Son and the Holy Spirit; and this thanksgiving to God for vouchsafing us worthy of these His creatures, is of a prayer of more than ordinary length. When the bishop has finished the prayers and the thanksgiving service, all the people present conclude with an audible voice, saying Amen. Now Amen in the Hebrew tongue is, 'So it be.' The Eucharistical office being thus performed by the bishop, and concluded with the acclamation of all the people, those we call deacons distribute to every one present to partake of this Eucharistical bread [and wine] and water, and then they carry it to the absent.

"This food we call the Eucharist, of which none are allowed to be partakers, but such only as are true believers, and have been baptised in the laver of regeneration for the remission of sins, and live according to Christ's precepts; for we do not take this as common bread and common wine; but as Jesus Christ our Saviour was made flesh by the Logos of God, and had real flesh and blood for our salvation, so are we taught that this food, which the very same Logos blessed by prayer and thanksgiving, is turned into the nourishment and substance of our flesh and blood, and is in some sense the flesh and blood of the incarnate Jesus. ..." "After this sacrament is over, we remind each other of the obligations to duty, and the rich relieve the poor; and upon such charitable accounts we visit some or other every day."

Justin adds the significant complaint quoted above on page 353 , last paragraph, that through a strange contrivance of the evil spirits the same ceremony was celebrated in the same way by the worshippers of Mithras, the Christ of Mazdaism.

That in the days of St. Paul the Pagans celebrated love feasts which resembled the Christian sacraments becomes manifest from the contrast which appears in the apostle's speaking of the Lord's cup and the cup of devils, that is to say, of the Pagan deities.

We notice at the time of Justin Martyr one important change in the Christian sacrament since the days of St. Paul. The celebration of the Eucharist is no longer a real meal, as it was in Jeru-

${ }^{1}$ Harnack regards the mention of the wine as an interpolation, as will be seen later on, and claims that the elements of the Lord's Supper in the early Church were as a rule bread and water, and only exceptionally bread and wine. 
salem among the Nazarenes and in the congregation at Corinth, but has become a purely symbolical partaking of the sacred bread. In the days of St. Paul the Lord's Supper or Eucharist was identi-

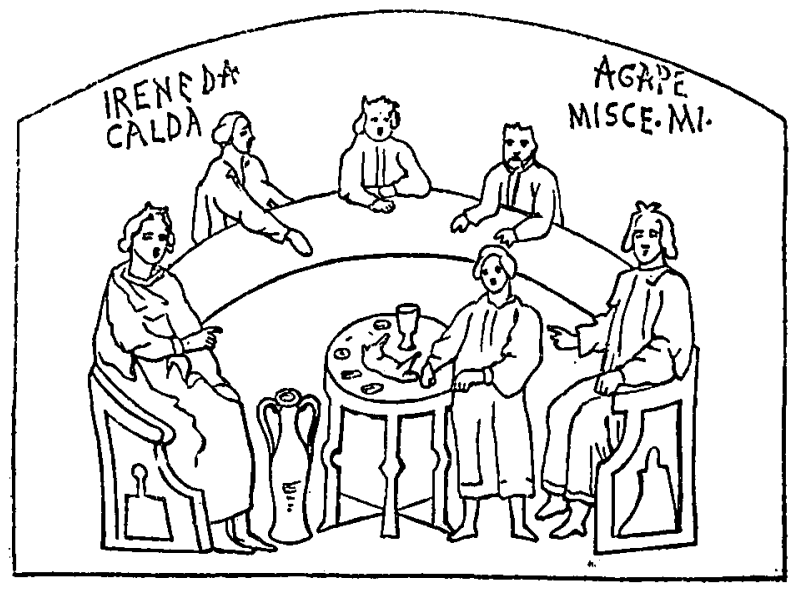

Christian Love Feast.

Fresco in the cemetery of St. Pietro e Marcellino.

cal with the agape or love feast, the Roman charistia. When the communion (i. e., the meal taken in common) under the influence

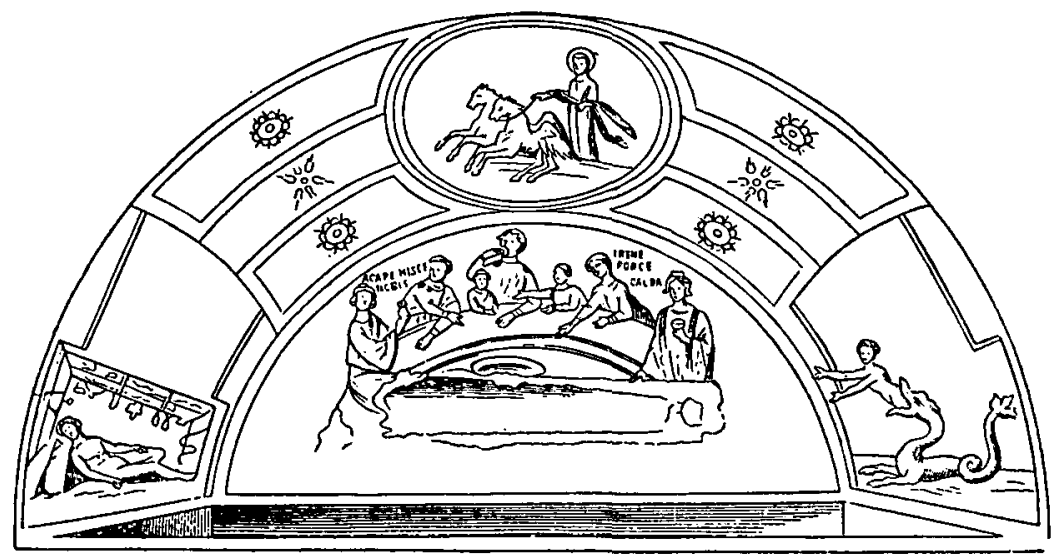

Christian Love Feast.

Fresco in the cemetery of St. Pietro e Marcellino.

of St. Paul's conception of it, ceased to be a real meal and changed into a mystical ceremony after the pattern of the Mithraistic ritual, the agapes continued to be celebrated and we find now two distinct 
institutions, the mass and the agape or brother-meal. The latter is frequently pictured in the Catacombs, and we reproduce here one of the most typical representations of it, which was discovered in a subterranean chapel in the cemetery of Marcellinus and Peter.

Charles Maitland, in his interesting book, The Church in the Catacombs: A Description of the Primitive Church of Rome, speaks of the subject as follows (p. 209):

"In this painting the three guests are seen seated, and a page supplies them with food from the small round table in front, containing a lamb and a cup. The two matrons who preside, personifying Peace and Love, have their names written above their heads, according to the Etruscan practice.

"The inscriptions should be read: 'Irene-Da calda ( $m$ aquam); and, Agape -Misce mi (vinum cum aqud),' i. e., 'Peace, Give hot water; Love, Mix me wine.

"The original Agape, or love-feast, was a truly Catholic element of ancient Christianity. Begun in the purest spirit, it shared the fate of some other ordinances, till in the fifth century it became a scandal to all Christendom. It is first mentioned by St. Jude, in the passage, 'These are spots in your agapæ,' $\varepsilon v$ tais $\dot{a} \gamma \dot{a} \pi a \iota \varsigma \dot{v} \mu \tilde{\omega} \nu$, translated in our version, 'feasts of charity.' "'

How similar the Pagan love feasts were to the Christian eucharist appears from the similarity of the pictures of both institutions; and both were held to have same mystic reference to the life beyond the grave. We here reproduce the illustrations of the tomb of Vibia, wife of Vincentius, a priest of Sabarios (Dionysos). Vibia is snatched away by Pluto after the manner of the rape of Proserpine, Hermes, the leader of souls to Tartarus leading the way. In the second picture she appears led by Hermes and Alcestis (the classical prototype of a faithful wife) before the throne of Dispiter and Aeracura, the Jupiter infernus and Juno inferna. Three fates attend the scene. ${ }^{2}$ The gesture of the judge indicates that Vibia is deemed worthy of being admitted to the bliss of Ely-

\footnotetext{
${ }^{1}$ Maitland is mistaken in several points; the first mention of the Christian "agape" is not by St. Jude, but in St. Paul's Epistles, and the excesses of the Christian love-feasts did not make their appearance later on, but were noticeable at the very start. We may assume that the Pagan love-feasts were sometimes not much better.
}

${ }^{2}$ It is strange that one of the fates is apparently a man. 
sium; and an angel ${ }^{1}$ (angelus bonus) conducts her to the eucharist of the blessed in the Elysian fields. On the third picture Vibia appears twice at the entrance and at the table of the celestial banquet.

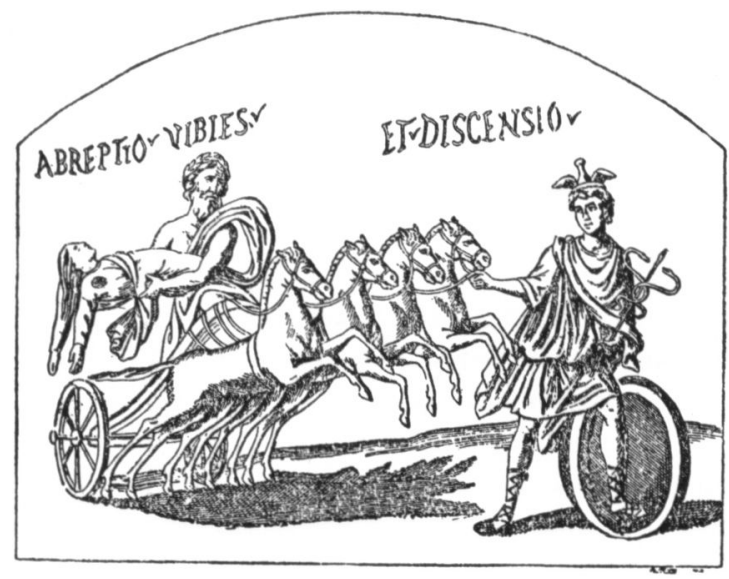

The Rape of Vibia and Her Descent.

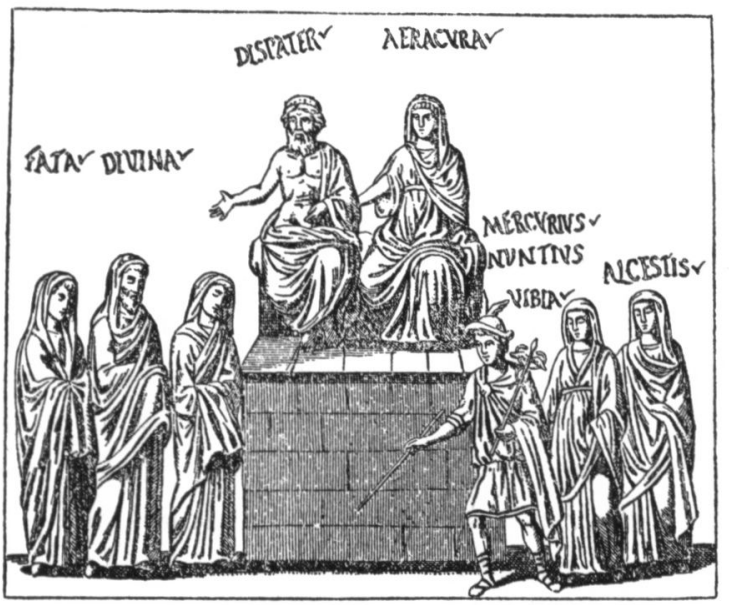

Before the Tribunal of the Ruler of the Nether World.

The last picture shows Vincentius himself as one of the seven priests of Sabazios seated at the Dionysian eucharist. Each loaf

1 The idea of angels is not exclusively Christian but was quite common in classical antiquity at and long before the age in which Christianity originated. Plato speaks of "the angel of Elysium" in Rep. X. p. 6r9 B. 
of bread on the table bears an equilateral cross with dots between its arms, according to ancient Roman custom. ${ }^{1}$

THE PROBLEM OF THE INSTITUTION OF THE LORD'S SUPPER.

Justin quotes in his report the institution of the Lord's Supper from the memoirs (apomneumata) of the apostles called the gospels

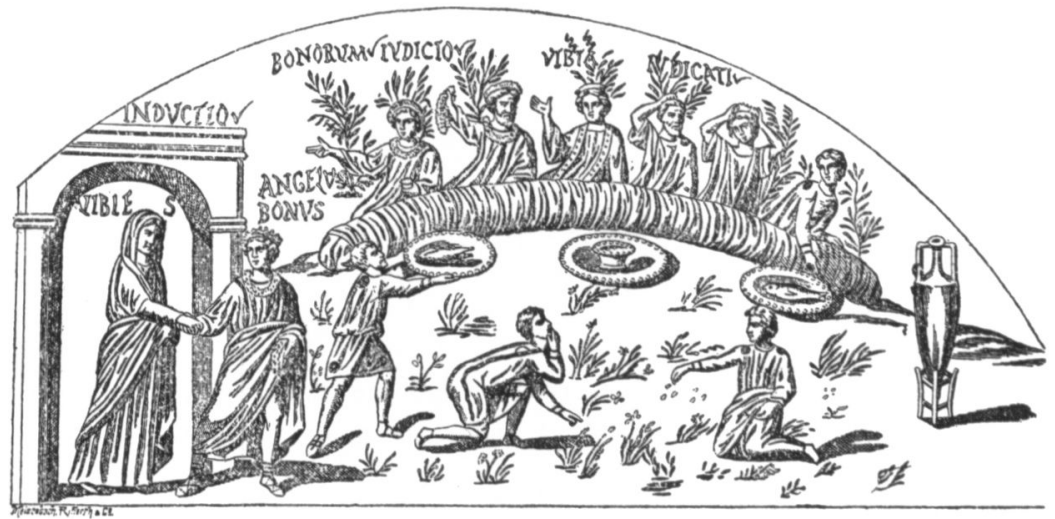

The Love Feast in the Elysian Firlds.

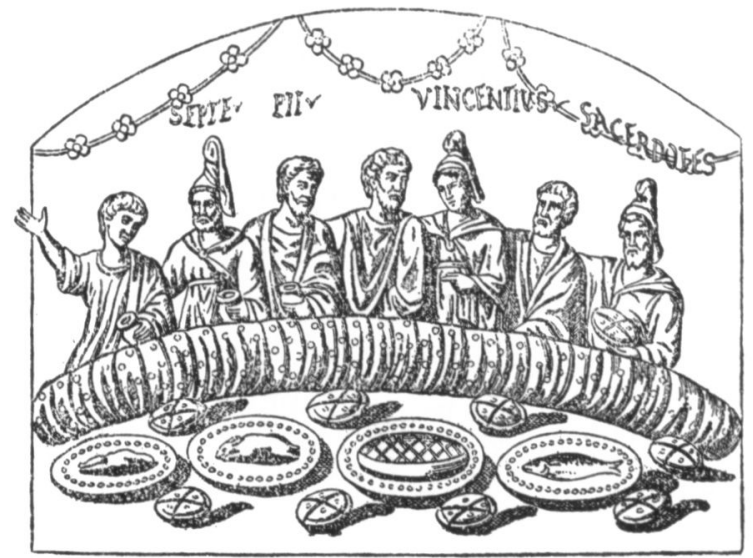

The Seven Priests, Vincentius Among Them.

(which of course need not be our Gospels) and it is true that Mark, the oldest, and also Matthew and Luke contain the Eucharist formula in almost the same words. In addition the formula is mentioned in the so-called apostolic traditions which are supposed to

1 The illustrations are reproduced from Ernst Maass, Orpheus. 
have been established in the second century A. D., but may, in part, reach back to the earliest days of Christianity. As the Gospels in the shape in which we have them are later than the Epistles of St. Paul, the theologians of the critical school deem it probable that the Gospel accounts of the institution of the Lord's Supper are influenced by St. Paul's views. Mark (whom Luke and Matthew follow almost literally) describes the institution of the Lord's Supper as follows :

"And as they did eat, Jesus took bread, and blessed, and brake it, and gave to them, and said, Take, eat : this is my body.

"And he took the cup, and when he had given thanks, he gave it to them: and they all drank of it.

"And he said unto them, This is my blood of the New Testament, which is shed for many.

"Verily I say unto you, I will drink no more of the fruit of the vine, until that day that I drink it new in the kingdom of God." (Mark xiv. 22-25.)

As to the use of the drink we shall notice on a careful perusal of the passages in question that Paul, as well as the Gospel writers, carefully avoids any definite designation, but speaks of the cup only, which, according to Paul's testimony, Jesus called "the cup of the New Testament in my blood."

Justin (at least in those MSS. from which most of the present text-editions have been made) speaks of water and wine, and at present pure wine is used in the sacrament. But we know that the oldest churches were not limited to a definite drink, but frequently used water. It was only with the consolidation of the Church under Roman influences and when its institutions assumed a definite shape that the nature of the drink was officially prescribed by ecclesiastical authorities to be a mixture of wine and water which was later on changed to pure wine, and those congregations who did not obey were ostracised as heretics.

Professor Harnack's Essay on Bread and Water ${ }^{1}$ contains irrefutable evidence that the elements of the sacrament were not definitely determined among the early Christians. Even as late

1 Published in Texte und Untersuchungen zur Gesch. der Altchr. Literatur VII, 2 pp. II $5^{-1} 44$. 
as the fifth century many Christian congregations celebrated the Eucharist by partaking of bread and water alone. Not only did the Ebionites and other sects of ascetic tendencies abstain from wine in the sacrament, but we know positively from the sixty-third letter of Cyprian that the Catholic Churches of Africa clung to the same practice and African bishops are quoted as claiming in their favor (I) the authority of the scriptures, (2) the commendability of the practice and (3) tradition. We must remember that the wine as the drink of the Lord's Supper is nowhere explicitly mentioned in the New Testament, and St. Paul, apparently not without some good reason, uses the non-commital term morńpıov (drink), when we should expect the word "wine." Cyprian's condemnation of the use of water as a heretical practice and the weakness of his arguments are the best proof that the African tradition was neither isolated nor limited to ascetic circles, but based upon an old and well established authority. Professor Harnack believes according to the Gospel report, that Jesus at his last supper drank wine and not water, but he claims that water was the usual and preferred drink of the Lord's Supper among the early Christians which can be established on the authority of Justin the Martyr who never speaks of the wine of the sacrament, and once speaking of the water of

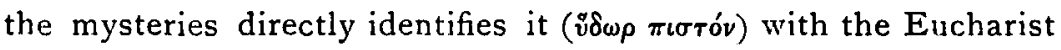
cup.

Further whenever Justin mentions the blessing of Juda, where Juda is compared to a vine, or to the fruit of the vine, the grape, or where he compares Christ with Dionysus, the God of wine, he never mentions the Eucharist.

The reading oivos in two passages of the latter kind is a corruption of the text for orvos. Thus the fact that both Dionysus and Christ make their entry on a donkey is more striking to Justin than the symbolic significance of the wine in both religions. In three other passages the words oivos, wine and $\kappa \rho \hat{\mu} \mu a$ mixed drink, appear by the side of the terms "bread and water," but they are

\footnotetext{
${ }^{1}$ For further details we refer the reader to Professor Harnack's essay "Bread and Water the eucharist elements of Justin." Hinrich'sche Buchbandlung. 1891. In Texte und Untersuchungen, VII, 2.
} 
spurious as they do not appear in the Ottabian codex. Obviously (Professor Harnack argues) later interpolators or copyists took offense at the expression "bread and water" and deemed it necessary to add the word "wine" or "mixture" (oivos or $\kappa \rho \hat{a} \mu a$ ). Professor Harnack concludes (p. I3I).

"Justin describes the Christian worship as using in the Lord's Supper bread and water not bread and wine. His disciple Tabian accordingly did not introduce an innovation. And a few comments are needed to set forth the importance that Justin who was at home in Ephesus and Rome, and in fact in all Christendom, and who describes the worship of the Roman Church, makes no mention of the wine, and describes the ceremony as being of bread and water."

Harnack sums up his conclusion in these sentences:

" The institution of the Lord was originally understood in a sense which makes the blessing attach, not to bread and wine, but to eating and drinking. Bread and wine is a very simple meal, bu: bread and water is simpler still. The elements of the Lord's Supper, accordingly are bread and the cup.

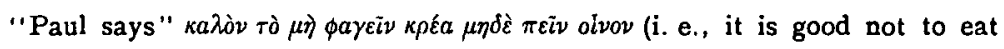
meat nor to drink wine), but it is a mean subterfuge to say that here the wine of the Lord's Supper must be excepted. . . If Paul praises abstinence from wine, he includes abstinence from wine at the Lord's Supper, and thus he declares that the cup of water is sufficient.

"The Lord's Supper in the circle of the first disciples was a daily and a real meal (Didache ro uses the term $\dot{\varepsilon} \mu \pi \lambda \eta \sigma \vartheta \tilde{\eta} \nu a \iota, i$. e., to eat one's fill), and probably bread and wine were used. But from the beginning the breaking and eating of the bread was the essential part, for it was a meal that was being celebrated. At the meal a drink was taken, and that was drank as the blood of Christ. This was (especially among the poor) sometimes water. Of the Ebionites of Palestine we know that they took bread and water as their sacrament and in addition to their lack of wine there was another reason. Even in the apostolic age there were some who made of wine drinking a matter of conscience, and Paul requested Christians to be lenient with such narrow consciences.

"Thus the custom of taking the Lord's Supper under the form of bread and water, as a real meal, increased from $64-150 \mathrm{~A}$. D.; and became so well established that Justin in his description of the Lord's Supper makes no mention of wine at all.

"It is only the Apostolic Catholic Church which introduced the wine as the sole element of the institution; and in this case she was at least in formal agreement with Christ's inauguration."

Harnack adds :

"The Church had a right definitely to prescribe in times which no longer could brook liberty, the elements of the first Lord's Supper, especially when there 
was a demand for water and when a motley variety of foods began to endanger the dignity of the ceremony. But this advance had its serious drawback for as soon as the elements were determined the superstition became unavoidable that the power of the sacraments was inherent in its elements."

We have quoted Professor Harnack extensively because of the importance of the results of his investigations, and we need not here quarrel with him about principles. He seems to think that in the first century the early Christians were entitled to have liberty, but later on the Church had a right to suppress the consciences because later ages could no longer brook liberty. Uniformity which was needed for the centralisation of the power of the Church became more essential than personal convictions. If in Paul's time the Christians were free to take either wine or water, why should we of the nineteenth century not have the same right. Some Chinese converts who hold the alcoholic drinks of the west in abomination use tea, but their practice is denounced as utterly un-Christian by the Episcopalians. ${ }^{1}$

My friend, Dr. G., a member of the Church of England and a

'See, for instance, the missionary report in the little monthly The Church in China, Vol. IV., No. I2, pp. 149-150: "The Angelus, the parish paper of the "Church of the Ascension in Chicago, published to the world that here was some"thing very wrong indeed in China; the missionaries were using tea instead of "wine in Holy Communion. Next, a professor of one of our theological seminaries "wrote to the Living Church and restated the charge, and demanded 'the utmost ' 'publicity.' Two good friends of the Mission were prompt in denying the charge, "but meanwhile the mischief is done. People who will never see the denial will " hereafter refuse to contribute to the Mission on the ground that we are not to be "trusted. One priest has even gone so far as to write that 'many may feel called " upon to abjure the Communion of a Church where such things are allowed,' " and quite a little excitement seems to have been caused in many quarters. Now "we do not wish to make light of such a charge if it were true. To substitute any"thing whatever for the wine in the Sacrament would be to break with all Church "tradition, to meddle presumptuously with the institution of our Lord, and thus " to commit sacrilege. (!) If a priest or bishop were found to have done so he ought " to be tried and deposed.

"But it is just because the offence is so grave that we ask our critics how they "could find it in their hearts to impute it to the Bishops and clergy of the China "Mission. On the one side is all Church law and custom and the character of the "men who are sent out from home to do a difficult work. On the other, an am"biguous sentence in a letter of one man new to the work. Do not make our task " harder by foolish criticism or harsh charges. Be a little just, and generous, and "charitable." 
vigorous anti-teetotaler, endorses these sentiments and declares that wine is under all circumstances the better drink.

Harnack seems to assume that Jesus instituted the Lord's Supper personally, but a close inspection of the Gospel reports will show that such is not the case.

In spite of Paul's and Justin's definite statements, that Jesus instituted the Lord's Supper on the night in which he was betrayed, Christian theologians have been forced to the conclusion that the event is not historical but the product of an interpretation of the Lord's Supper as an ancient Church institution which was commonly supposed to be founded by Jesus himself.

Paul's view of the Sacrament may have given the first stimulus to celebrate it in commemoration of his death, and is at any rate the oldest statement that is historically unobjectionable. The reports of the three Gospels are of a later date and may very well directly or indirectly be dependent on Paul. The strangest thing is that the Fourth Gospel (which is named after St. John) does not contain the least reference to the institution of the Eucharist; and yet the author of this Gospel, whose conception of Christ as the bread of life brings him into sympathy with the fundamental idea of the Lord's Supper, would have made him hail the idea of the Eucharist in which Christ symbolically gives himself up as food to those who are his own.

One of the most important differences between the three Synoptic Gospels and the Fourth Gospel consists in this, that Christ was crucified according to the former on a Saturday, according to the latter on a Friday; but a critical-textual investigation proves that the original reports agreed better than the versions which we now possess.

The high-priest and his councilors, according to Mark, are in a hurry to have Jesus executed before the Passover Feast, and then we read that Jesus celebrated the Passover with his disciples, and the account of it is so explicit as to leave no doubt. The contradiction finds its explanation in the idea which prevailed among the early Christians that the Sacrament was the Jewish passover or pascal, and Christ, the pascal lamb of the new Cove- 
nant, should have instituted the Lord's Supper on the Feast of Passover. This thought pervades some passages which bear the characteristic marks of interpolations; and he who tampered with the text forgot to change the other passages according to which Jesus must have been crucified before the feast. The addition made to the text includes the celebration of the Last Supper, and the fact that we have to deal here with an interpolation must naturally discredit the three reports which in this very place have obviously been tampered with. If the institution of the Lord's Supper had been a part of the original Gospel of Mark or of any genuine apostolic memoir, the author of the Gospel according to St. John, who knew and used these oldest Gospels, would not have forgotten to incorporate it in his book.

Spitta, though recognising the great importance of Harnack's essay, criticises him for reconstructing the Last Supper from postapostolic traditions and rejects the idea of its being instituted by Jesus at his last supper, saying:

"Of an institution (of the Lord's Supper) by Christ on the last day of his life, there is not the slightest trace in the oldest tradition." (P. 332.)

Spitta ${ }^{1}$ proposes for practical Church use the interpretation of

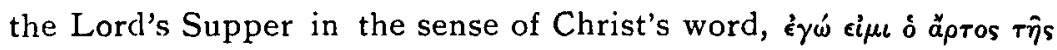
$\zeta \omega \eta \hat{s}$, - I am the bread of life,- and would thus replace the gloomy and funereal mode of its celebration by a more elevating conception, not as a mysterium tremendum, but as a feast of joy and gratitude. And this conclusion is forced on him-a man of decidedly conservative, if not orthodox, tendencies-against his previous conviction upon purely historical evidence and the internal evidence of the text.

We cannot enter into further details and refer the reader to Professor Spitta's thoughtful article on the subject, which is the work of an orthodox Christian, i. e., of an ardent believer, a theological professor of the University of Strassburg, who takes a very active part in practical Church work. His present view has been

${ }^{1}$ Zur Geschichte und Literatur des Urchristenthums, p. 208. 
forced on him by the overwhelming evidence of facts. He says of his own views :

"The following essay contains a severe self-criticism. What I offer is nothing else than the result of that which the power of historical tradition as well as I understand it has forced upon me."

In addition to historical reasons, which render the view that the Lord's Supper was instituted by Jesus impossible, there are other arguments which should not be underrated. The Christians of to-day are accustomed to the words, "This is my body," and "This is my blood"; but to the Apostles these terms were strange. Nor did Jesus prepare them otherwise than by the prophecy of his death. This, however, aggravates the situation and renders the words the more offensive, ghastly, and abhorrent.

Consider only the situation: The revered Master takes leave, because he must die, and he declares in the last meal that the bread which he breaks and offers to his disciples is his body, his very flesh, and the wine his blood. The impossibility of such a declaration at such a moment is obvious! The very idea of identifying the bread with the Lord's flesh that will be broken on the cross, would under these circumstances have been so uncanny as to make his disciples unable to swallow the least morsel of it. The audience of Jesus did not consist of cannibals of ancient Egypt or darkest Africa, but of Jews. The wine as blood, not for sprinkling but for drinking, would have become disgusting to Israelites who through the Mosaic law had become accustomed to regard the drinking of blood as a most sinful defilement.

THE INFLUENCE OF ST. PAUL'S CONCEPTION.

If the Gospel report of the institution of the Lord's Supper must be ruled out of court, we find ourselves at last face to face with the statement of St. Paul that he received it "as a word of the Lord." His is the only testimony the historical genuineness of which cannot be doubted. But even if we suppose that Paul had actually received the institution of the Lord's Supper by a visionlike communication, we cannot help thinking that the conception of his intuition must have come to him from somewhere. 
Owing to the authority which Paul possessed, his mode of celebrating the Eucharist must have at once been widely introduced among the Gentile Christians, and must have done much toward determining the spirit, and perhaps even the form, in which it was celebrated.

St. Paul is a thinker of great depth, but he is neither an historian nor a critic; he is a theologian who takes convictions which are to him of fundamental importance as revelations and proclaims them as words of the Lord. How little he cares for historical information concerning Jesus appears from the fact that he intentionally avoided the Apostles for a long time, and goes so far as to boast :

"I certify you, brethren, that the gospel which was preached of me is not after man."

Only when his views had been definitely settled, Paul sought the Apostles for their indorsement of his doctrines. Peter and Paul did not agree, but Peter suffered Paul so long as he confined himself to the Gentiles and promised to remember the poor.

The way in which Paul proclains his conviction as a word of the Lord is very impressive, but we must consider that on other occasions he is very unfortunate with his statements. An essential part of St. Paul's Christianity was the doctrine of the day of the Lord as being near at hand; and the faithful believers expected to be literally taken up to the heavens at the advent of Christ. Their faith began to be shaken when several of them died before the fulfilment of their hopes and to comfort the survivors St. Paul pronounces the prophecy:

"For this we say unto you by the word of the Lord, that we which are alive and remain unto the coming of the Lord shall not prevent them which are asleep.

"For the Lord himself shall descend from heaven with a shout, with the voice of the archangel, and with the trump of God: and the dead in Christ shall rise first.

"Then we which are alive and remain sball be caught up together with them in the clouds to meet the Lord in the air : and so shall we ever be with the Lord.

"Wherefore comfort one another with these words."

No quibbling can set this prophecy in a light which could interpret away its non-fulfilment, or soften the crudity of his escha- 
tology. And this promise St. Paul made to his followers as a word of the Lord!

St. Paul is a peculiar mixture of clear thought and mysticism. $\mathrm{He}$ is clear in his arguments and explicit in his statements, and those convictions which he holds for reasons unknown to himself appear to him as direct communications of a higher source.

The psychology of St. Paul is not an exception but the rule. Convictions which rest on sentiments are commonly regarded as divine, and any literature which is a direct outpouring of the heart, be it poetical or religious, is considered as inspired. Thus when Paul makes a certain statement as a word of the Lord, we must assume that the source of his conviction is an inner voice which wells up, in the same manner as does conscience, out of the depths of his unconscious soul-life.

We have explained in another article that Gnosticism (using here the term in its broadest significance) was a religious movement antedating Christianity and that Paul was thoroughly imbued with its spirit. He employs the gnostic terms not as denoting new ideas but as referring to well known notions. His education was Jewish of the most orthodox school, but it was modified by the spirit of his surroundings which as we know were saturated with Greek thoughts such as prevailed in those days in Asia Minor; and Asia Minor was a hotbed of Gnosticism.

By Gnosticism in its broadest sense we do not understand any one of its special systems, be it the system of the Ophites or any other Gnostic sect, but the whole fermentation which through the mingling of the nations and the mutual exchange of thought began to agitate the religious world from the days of Alexander the Great. It is not the place here to analyse the problems which were raised in those days and to assign them to their various sources, India, Persia, Egypt and also to the ancient traditions of Babylon, Assyria, and Accad. Suffice it here to state that new ideas concerning the nature of the soul, its relation to God, and its destiny after death were discussed and many wild theories as to the origin of the world and the end of all things with a subsequent renewal were widely entertained by many people. A saviour was expected, not by the Jews alone, 
but by almost all the nations, especially by the Persians. Paul had unconsciously imbibed all these notions. How could he, growing up as he did in Tarsus, help it? You might as well educate a German boy in America, and expect him to remain ignorant of the American spirit and the notions of progress and liberty with which the atmosphere of the United States is saturated. Thus we may fairly assume that Paul cherished a great number of thoughts of which he could give no account to himself because he had imbibed them in his early childhood.

Have we perhaps to deal with such a notion in Paul's doctrine of the Sacrament?

The question is difficult to decide, but there is one thing of which we may be sure, viz., that similar ideas were prevalent among various religious sects, among which the Mithras worshippers perhaps come most closely to Paul's conception of the sacrament. The Myazda offering was frequently celebrated in commemoration of the dead and taken as food of life which would assure its participants of their resurrection at the great day of judgment. When Mazdaism spread, Mithras worship became more and more prominent, and we may assume that it incorporated many religious notions of the less civilised people who adopted its faith. Was it not natural that the idea of the power of atonement inherent in the blood of sacrifices should be connected with the Myazda offerings? Such notions prevailed among all the races of Asia and Africa as well as among the Gauls and Thracians and had entered into the sphere of Greek thought through the Dionysian and other mysteries. The monuments of the Mithras mysteries which are frequently found in the northern Roman border-provinces along the Rhine and the Danube can be adduced as unequivocal evidence of the rôle which the idea of blood as the sacred liquid of salvation played in the Mithraistic eucharist.

Blood covenants are an established institution among all the pre-Christian religions of the earth, and the idea of their sacredness was deeply rooted in the hearts of the people. ${ }^{1}$ Blood cove-

${ }^{1}$ See The Blood Covenanl, a Primitive Rite and Its Rearings on Scripture, by H. Clay Trumbull, D. D. London, George Redway, 1887 . 
nants are survivals of barbarism, but to Jews and Christians both the idea itself and the term were sanctified through scriptural use. For we read in Exodus xxiv. 8:

"And Moses took the blood, and sprinkled it on the people, and said, Behold the blood of the covenant, which the Lord hath made with you concerning all these words."

It is but natural that the idea of the blood covenant formed an ingredient of the gnostic fermentation of thought; and it seems that the hoary traditions of human sacrifices, as well as the vicarious death and resurrection of a Dionysus, an Adonis, a Thammuz were connected with the practice of blood covenants. The principle of vicarious atonement is the underlying theory of all sacrifice as instanced in the practice of the Mosaic law of transferring the sins of the people upon the goat offered on the altar.

A new conception of the idea of sacrifices were in the air and cannot have remained unknown to Paul. When his whole life was suddenly changed through the vision on the road to Damascus, he saw the world in a new light, and his gnostic notions began to receive a satisfactory interpretation. They must have remained an unintelligible portion of his soul, which may have collided now and then with the system of his pharisaic schooling. But when he conceived the idea of the Messiah as having appeared in the flesh and having died in contumely and as being resurrected in glory, the two currents of his thought were reconciled, and the dim traditions of ruder ages, the mysterious notions of unknown sources, appeared now as prophecies that had found their fulfilment. Paul must have felt the more sure of having the right solution as the most ancient, the most venerable, the most reliable, though at the same time the most bloody and cruel and desperate methods of salvation were thus justified in principle, while the rites themselves which (perhaps not without serious misgivings among a large portion of the most earnest religious minds) had become antiquated, could now at last be regarded as fulfilled in, and finally abolished by, the death of Jesus.

Considering the religious disposition of mankind, the belief in the atonement through the blood of Jesus was a doctrine that could 
set to rest the minds of the people and serve as a transition to a nobler conception of religion. It developed spontaneously, being a natural product of the age, and if Paul had not proclaimed it, some one else might have uttered a similar thought. It was a matter of historical necessity that he who formulated it should become the religious leader of the age.

If in the progress of civilisation the development of thought rises to a higher plane it will discard the lower religions that prevail at that age, for a higher religion; but let us not forget that this higher religion, in order to be acceptable to the people should not only be better, purer, and truer, but must also come as a fulfilment of the older faith. The Christianity of Christ came as a fulfilment of the Old Testament, and the Gentile Christianity of the Roman Church, in order to be acceptable to the Pagans, could not help being a fulfilment of ancient Pagan rituals and beliefs. From the Protestant standpoint the development of the Christian Church during its Romanisation appears as a falling from grace and a lamentable lapse into Paganism, but from the standpoint of a calm historian who is not swayed by sentiment and endeavors to understand historical events, this period appears as the unavoidable result of given conditions. It was a necessary period in the evolution of religious thought and could not have been otherwise.

The task of preparing the movement fell to the part of a Hellenised Jew, which is not an accident but a matter of course. The apostle of the new covenant might as well have come from Egypt as from Asia Minor. Philo, if he had lived a decade later, might have done the work as well; but at any rate, it was essential that it should be a Jew born and raised in a centre of the intellectual life of orientalised Hellenism, so as to unite in himself all the premises of the religious problem of the age. Judaism alone could become the centre of the new faith that was to be the result of the Gnostic fermentations, because the Jews were a nation in possession of an accessible religious literature chastened in the furnace of a pure and almost Puritanic monotheism. Judaism alone could furnish the backbone of the new faith. Neither the Egyptian Thoth, nor any of the Greek saviours, Dionysus, Hermes, Hercu- 
les, etc., nor the philosopher among healers, Apollonius of Tyana, nor even Mithras, had any chance in this competition for the place of honor, with the Jew Jesus, the simple-minded Nazaree, whose Messianic mission became sanctified by his death on the cross, for thus the new religion was set in relation to the ancient traditions of atonement by blood in a real human sacrifice. The Gospel of the Crucified was a fulfilment of the old beliefs as awful and soulstirring as the cruelest of them, yet implying a radical abolition of the barbarism of bloody sacrifices.

EDITOR. 